\title{
Pandemic and Õen Consumption in Japan: Deliberate Buying to Aid the Seller
}

\author{
Kosuke Mizukoshi \\ Tokyo Metropolitan University \\ Yuichiro Hidaka \\ Okayama University
}

Follow this and additional works at: https://digitalcommons.uri.edu/mgdr

Part of the Anthropology Commons, Economics Commons, Japanese Studies Commons, Marketing Commons, Other Business Commons, Public Health Commons, and the Sociology Commons

\section{Recommended Citation}

Mizukoshi, Kosuke and Hidaka, Yuichiro (2020) "Pandemic and Õen Consumption in Japan: Deliberate Buying to Aid the Seller," Markets, Globalization \& Development Review. Vol. 5: No. 3, Article 3.

DOI: 10.23860/MGDR-2020-05-03-03

Available at: https://digitalcommons.uri.edu/mgdr/vol5/iss3/3

This Dialogue is brought to you for free and open access by DigitalCommons@URI. It has been accepted for inclusion in Markets, Globalization \& Development Review by an authorized editor of DigitalCommons@URI. For more information, please contact digitalcommons-group@uri.edu. 


\section{Markets, Globalization \& Development Review}
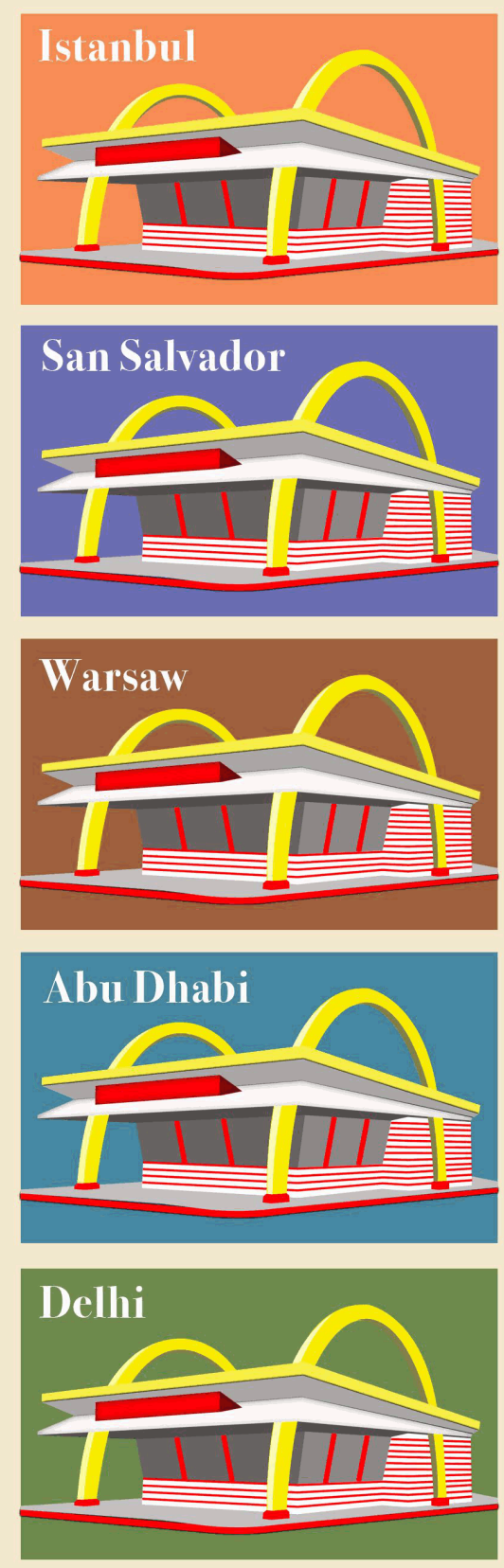
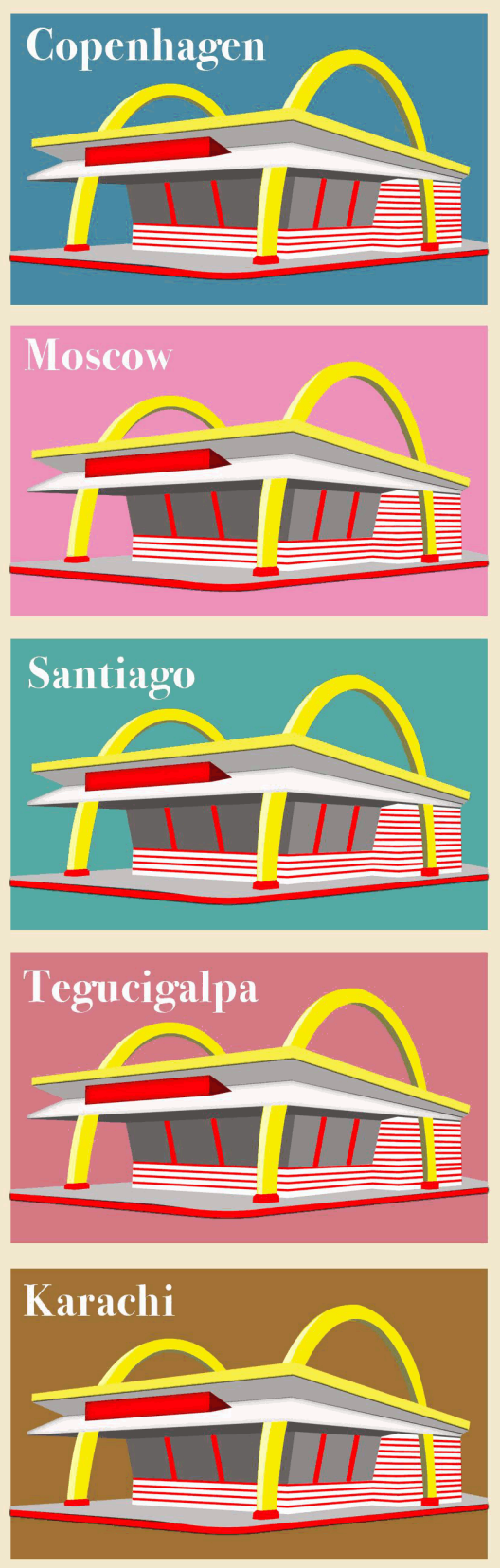
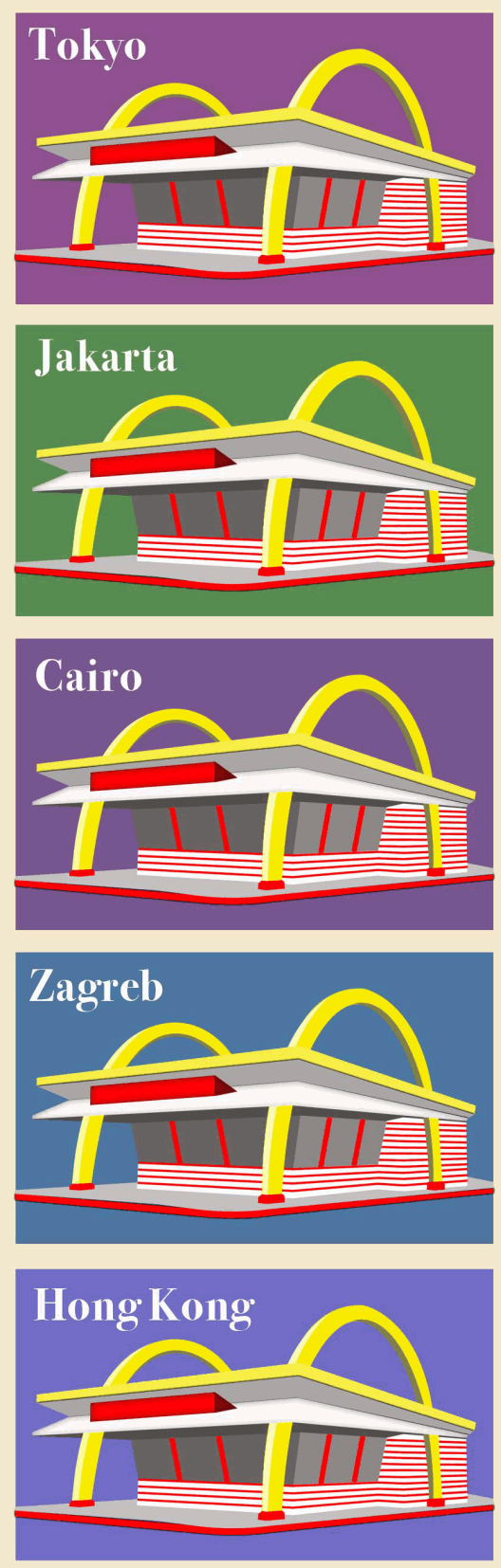

This dialogue is available in Markets, Globalization \& Development Review: https://digitalcommons.uri.edu/mgdr/ vol5/iss $3 / 3$ 


\section{Pandemic and Õen Consumption in Japan: Deliberate Buying to Aid the Seller}

Note from Editors: The Japanese term Ouen (応援), sometimes expressed in English as Õen, is a popular and multivalent expression meaning "to aid, to support, rooting for, cheering for" etc.

\section{Depression in COVID-19}

The world economy went into a global depression due to the impact of COVID-19. Consumers' spending was significantly restrained, and the effect on the local economy was enormous. The Japanese economy was been hit hard by the slump in global brands and the sharp decline in tourism. From April to August 2020, the number of foreign tourists visiting Japan decreased by $99.9 \%$ year-on-year according to the Japan National Tourism Organization (https://www.jnto.go.jp/jpn/).

During the pandemic, the meaning of consumption also changed. Capitalism has been dependent on endless consumption; on the other hand, there are now growing numbers of anti-consumerists (Kotler 2020). Economic stagnation may promote different, sustainable, but limited consumer behavior (Cambefort 2020). Leisure time and digital usage are also changing dramatically (Hong 2020).

In Japan, the symbolic phenomenon of Õen (aid) consumption is increasing. This means supporting and helping local restaurants and producers by buying and consuming their services and products. It expands through online shopping and crowdfunding (Nikkei MJ 2020). In the ranking of the hit products and expressions of the 2020 pandemic year, the word "aid consumption" was listed in the second position after online tools such as Zoom.

In response to the new trend in consumption behavior, novel online mechanisms and marketing activities - to distribute crops and fish that can no longer be sold by conventional means - are also being developed rapidly. For example, when schools were closed, umaimon.com continued a vigorous campaign until May 7, 2020 - with the support of the Ministry of Agriculture, Forestry and Fisheries - to support suppliers of school lunches. The online Hokkaido product exhibition was also a great success, and provided a new approach for companies to reach audiences.

The term aid consumption was first used in Japan after the 2011 Great East Japan Earthquake (Stanislawski, Ohira, and Sonobe 2015). The focus then was on dealing with reputational damage to agricultural 
products caused by their proximity to nuclear power plants. Such aid consumption is linked to cause-related marketing and ethical consumption. Aid consumption - Õen consumption - is slightly different from causerelated consumption because the purchase itself implies support and help without the presence of other causes. In addition, unlike ethical consumption, the purchase itself does not give consumers additional benefits, such as being more natural or healthier. One of the reasons for the spread of aid consumption is the immaturity of donation culture in Japan and skepticism about non-profit organizations (NPOs) that generally collect donations (Stanislawski, Ohira, and Sonobe 2015).

Of course, similar consumption behavior is often observable. For example, if a consumer wants to find not only value in a product but also value in a partner for a favorite brand, purchasing the brand may have a similar meaning to support and help (Fournier and Alvarez 2012). The difference between this and aid consumption, however, is that, first, aid consumption has a wide range of targets and is not directed to a specific brand. Second, aid consumption is more like a donation than a symbolic brand purchase, and seems more akin to cause-related and ethical consumption.

Donations go in one direction - from the sender to the recipient as a gift. On the other hand, normal consumer behavior is bidirectional and based on the premise of exchange. Cause-related and ethical consumption are associated with solving social problems by activating exchanges by mediating donations and, conversely, increasing donations by using these exchanges. Aid consumption also attaches new meaning to payments by way of support and help for producers and service providers on the premise of the exchange.

Creating and considering exchanges is a time-tested marketing and markets theme (Mittelstaedt et al. 2014). When considered in this way, it can be said that aid consumption is not only a favorable form of new social assistance, but also the result of strong marketing and market functions. The penetration of market forces has surpassed pure altruistic behavior such as donations and gifts, by creating new and market-based forms of donations and gifts. Especially in Japan, donation culture is considered to be weak and ineffective. The question and challenge in Japan, therefore, is whether it is possible to create favorable new social assistance based on market rather than philanthropic principles.

\section{Gift Giving and Exchange}

Unidirectional gifts, including donations, have the power to create an asymmetric relationship between the sender and the receiver (Mauss 
1925). The sender will have a power, and the recipient will be in debt. Gifts are acts that force reciprocity among people, a notion based on the magic of mana. On the other hand, when selling or buying things, the selling and buying sides are equal, and the exchange of money for things is established. Money has the power to pay for asymmetrical relationships.

Lévi-Strauss (1950) maintained that mana stories were fictitious and that continued reciprocity was grounded in the continuous circulation of the objects. With Lévi-Strauss's reinterpretation of Mauss, we learn that exchange does not take place because of value, but rather that value emerges because of the exchange. Exchange, thus, does not take place to gain something. Instead, through exchange practices, the value of the goods emerges. As stated by Lévi-Strauss (1949), the focus is on the exchange rather than on the value of goods.

The exchange discussed by Lévi-Strauss does not refer to economic exchange where the purpose is to obtain a so-called fair price, but points to a form of exchange "for the sake of exchange" with the exchange itself being the objective of the practice. "The exchange relationship comes before the things exchanged, and is independent of them" and it exists "without any relationship with those goods" (LéviStrauss 1949: 139). Exchange is not carried out in order to obtain value at a fair price. The exchange is for the sake of exchange. Once we understand that the objective of kula trade based on mana is the exchange itself, we can see that the exchange is what creates value and that it is this kind of value through exchange that forms communities (Malinowski 1922).

Perhaps such a definition of exchange is not only applicable to primitive societies but also to our own society, where structurally similar systems of exchange exist, but now more commonly found on the Internet. Giesler (2006), for example, describes Napster, a peer-to-peer (P2P) music network, as a gift system akin to the ones described by Mauss. On Napster, people give and exchange items over the Internet, thus implying the existence of dyadic and network relationships. While in the mana era, no one could capture the whole exchange system, the Internet affords - at least theoretically, to one company or platform - the possibility of total systemic capture of all individual exchange acts.

Giesler (2006) indicates that gifts and exchanges require a system that supports and enhances them. Primitive society has a prototype of gift and exchange, but it is different from modern society, which is equipped with market mechanisms (Walter 2012). The generality of exchanges found by Lévi-Strauss is rather extreme, and gifts do overlap with exchanges, but for that purpose, a mechanism to support the exchanges 
is essential. Building and maintaining the market and macro forms of marketing activities are dominant themes in modern society (Mittelstaedt et al. 2014). It is necessary to reconsider exchange in the post-COVID-19 era, that is, how the market is structured and how it functions.

\section{Aid Mindset in the Market Principle}

Especially in Japan, as there is a culture where donations are not made, or at least not openly, it is difficult to make donations. It is great to donate, but a culture of intoku requires that at least you should hide it (Stanislawski, Sonobe and Ohira 2014). As Mauss (1925) showed, giftgiving implies a power relationship. Any act that makes others feel beholden and places the giver in an advantaged position should not be exposed. In addition, as a criticism of donations, it is said that donations cannot promote the independence of the other. Relationships that rely on donations will be maintained forever. Social marketing, which emphasizes working upstream, implements a transformation of the structure itself that creates people in need of donations (Gordon 2013).

On the other hand, in the case of purchasing and consumption, activities to make and sell things are important. The attendance of these activities gives the person an opportunity to break out of the relationship of relying on donations. The magazine The Big Issue operates by this logic (Hibbert, Hogg and Quinn 2002). It has been recognized worldwide for helping the homeless, but not by donating money to them, but by giving them the opportunity to sell its magazine. People pay a value that not only reflects the quality of the magazine, but also helps the homeless selling it. The Big Issue Japan is also in a big predicament due to COVID-19, but it is trying to get through the situation by moving selling activities to the Internet to support the sellers.

If both aid consumption and donations can support and help people in need, both will contribute to solving social problems. In particular, as a Japanese, it is easier to make a consumption choice than a donation, and if there is a greater possibility that the beneficiary will become independent, aid consumption is a better choice. It is better to encourage consumption to support a cause rather than just to solicit donations. Digital development has pushed globalization, but it has also strengthened our ties to the local (Firat 2016). Aid consumption is also important because it has become a means of saving the local producers, not global companies.

Aid consumption or Õen consumption, however, is part of capitalism and a new form of consumption behavior. This provides new reasons to facilitate exchanges. The mechanism that enables the promotion of the mind, whether internally or externally motivated, is based 
on governmentality as a power that symbolizes the market principle from a macro perspective (Foucault, 2007; 2008). While the introduction of market principles can encourage aid, this can also result in the loss of intrinsic social significance and make people economically minded.

Excessive reliance on market principles has often been discussed in critical marketing (Varman, Skålén and Belk 2012). People become unknowingly swallowed up by market principles, disciplined by them, and eventually continue to discipline themselves. Consumers seeking to take responsibility for environmental and social issues are formed through similar processes (Giesler and Veresiu 2014). The market mechanism transforms resistance in the more affluent consumption settings (FIrat 2016). Consequently, hopes that the market will provide a space for resistance or "consumer citizenship" (Arnould 2007) are often doomed to failure within cultures dominated by the market. If we do not pay attention to this point, it will be different from the flow of consumption in the new era. It is arguable whether the flow of consumption in the new era itself can deviate from or influence the market principle.

\section{Concluding Comments on Õen or Aid Consumption}

Since the COVID-19 being declared a pandemic, there has been a steady refrain - globally and in Japan - to as stay home and to keep 2-meters social distance. Social discontinuities continue to occur in various aspects of life. As mentioned at the beginning, many local industries and tourism activities in Japan are in a difficult situation, while people suffer from involuntary and compulsory constraints on their social connections. We barely stay connected to society online.

According to one survey, the key to aid consumption is sympathy for the business objectives of producers and a perceived direct connection to them (Nikkei MJ 2021). A manager of a crowdsourcing service says that the most distinctive feature of aid consumption under in the COVID-19 situation is that the aid comes from both producers and consumers (Kitahara, Takahashi and Namikawa 2020). Many producers put up products that consumers can enjoy together with their families at home to support consumers who cannot go out. The manager feels that the performers and supporters aid each other. Interest in aid consumption -helping and supporting via the market principle - is increasing. Charity (in these market-linked forms) for specific, rather than anonymous, local producers is increasing in the wake of the social disruptions of the COVID19 pandemic. Such aid consumption seems to suggest that direct connections and gratitude to local producers are becoming important and open, since we are suffering from intense social disconnections, and these 
buying and consuming methods offer ways to connect. Aid consumption may be a small light of hope for ensuring social cooperation - forms of commerce-enabled cooperative links that are spawned in the gaps and severances of social relations caused by the COVID-19 pandemic. 


\section{References}

Arnould, Eric J. (2007), "Should Consumer Citizens Escape the Market?," The Annals of the American Academy, 611 (1), 96-110. https://doi.org/10.1177/0002716206298698

Cambefort, Marine (2020), "How the COVID-19 Pandemic is Challenging Consumption," Markets, Globalization \& Development Review, 5(1), Article 2. https://doi.org/10.23860/MGDR-2020-05-01-02

Firat, Fuat A. (2016), "The Dynamics of the Local and the Global: Implications for Marketing and Development," Markets, Globalization \& Development Review, 1 (1), Article 4. https://doi.org/10.23860/MGDR-2016-01-01-04

Foucault, Michel (2007), Security, Territory, Population: Lectures at Collège de France 1977-1978. trans., G. Burchell, London: Palgrave Macmillan.

(2008), The Birth of Biopolitics: Lectures at Collège de France 1978-1979. trans., G. Burchell, London: Palgrave Macmillan.

Fournier, Susan and Claudio Alvarez (2012), "Brands as Relationship Partners: Warmth, Competence, and in-between," Journal of $\begin{array}{llll}\text { Consumer Psychology, } 22 & \text { (2), } & \text { 177-85. }\end{array}$ https://doi.org/10.1016/i.jcps.2011.10.003

Giesler, Markus (2006), "Consumer Gift Systems," Journal of Consumer Research, 33 (2), 283-90. https://doi.org/10.1086/506309 and Ela Veresiu (2014), "Creating the Responsible Consumer: Moralistic Governance Regimes and Consumer," Journal of $\begin{array}{lllll}\text { Consumer } & \text { Research, } & 41 & \text { (3), }\end{array}$ https://doi.org/10.1086/677842

Gordon, Ross (2013), "Unlocking the Potential of Upstream Social Marketing," European Journal of Marketing, 47 (9), 1525-47. https://doi.org/10.1108/EJM-09-2011-0523

Hibbert, Sally A., Gillian Hogg and Theresa Quinn (2002), "Consumer Response to Social Entrepreneurship: The Case of the Big Issue in Scotland," International Journal of Nonprofit and Voluntary Sector Marketing, 7 (3), 288-301. https://doi.org/10.1002/nvsm.186

Hidaka, Yuichiro and Kosuke Mizukoshi (2018), "From Social Marketing to Societal Perversion: History of Hometown Tax in Japan," Markets, Globalization \& Development Review, 3 (1), Article 3. https://doi.org/10.23860/MGDR-2018-03-01-03

Hong, Soonkwan (2020) "'Coronated' Consumption in the Viral Market," Markets, Globalization \& Development Review, 5 (1), Article 3. https://doi.org/10.23860/MGDR-2020-05-01-03 
Kitahara, Narinori, Takahashi, Hiroyuki, Namikawa, Susumu (2020), "Communication that supports Aid Consumption," Sendenkaigi Digital (in Japanese), (accessed on April 27, 2021), [available at: https://mag.sendenkaigi.com/brain/202009/aoyamameeting/019476.php]

Kotler, Philip (2020), "The Consumer in the Age of Coronavirus," Journal of Creating Value, 6 (1), 12-15. https://doi.org/10.1177/2394964320922794

Levi-Strauss, Claude (1949, 1969), The Elementary Structures of Kinship, New York: Beacon Press.

(1950, 1987), Introduction to the Work of Marcel Mauss, Routledge. Malinowski, Bronislaw (1922), Argonauts of the Western Pacific (Studies in Economics and Political Science), Kindle Edition.

Mittelstaedt, John, Clifford Shultz, William Kilbourne and Mark Peterson (2014), "Sustainability as Megatrend: Two Schools of Macromarketing Thought," Journal of Macromarketing, 34 (3), 25364. https://doi.org/10.1177/0276146713520551

Mauss, Marcel (1925), The Gift: The Form and Reason for Exchange in Archaic Societies (Routledge Classics). Kindle Edition.

Nikkei MJ (2020), "Consumption from Staying at Home Evolves under the COVID-19," Nikkei MJ, June 10, 2020 (in Japanese) , (accessed on May 2, 2021)

(2021), "Aid Consumption; Persistent even under the COVID-19," Nikkei MJ, March 12, 2021 (in Japanese) , (accessed on May 2, 2021)

Stanislawski, Sumire, Ohira, Shuji, and Sonobe, Yasushi (2015), "Consuming to Help -Post-Disaster Consumption in Japan," AsiaPacific Advances in Consumer Research, 11, 76-79.

Sonobe, Yasushi, and Ohira, Shuji (2014), "Japanese Consumers' Responses to Cause-Related Marketing on Product Packaging," Japan Forum of Business and Society, 3, 161-18.

Varman, Rohit, Per Skålén and Belk, Russell W. (2012), "Conflicts at the Bottom of the Pyramid: Profitability, Poverty Alleviation, and Neoliberal Governmentality", Journal of Public Policy \& Marketing, 31(1), 19-35.https://doi.org/10.1509/jppm.10.026

Walters, William (2012), Governmentality: Critical Encounters, New York and London: Routledge. 